\title{
THE
}

\section{Ohio Journal of Science}

PUBLISHED BY THE

Ohio State University Scientific Society

Volume XVIII JANUARY, $1918 \quad$ No. 3

TABLE OF CONTENTS

WITHRow-The Relation of War to Chemistry in America............65 OBERHOLSER-New Light on the Status of Empidonax Trailii (Audubon).. 85 SCHAFFNER - Additions to the Catalog of Ohio Vascular Plants for $1917 \ldots \ldots 99$

\section{THE RELATION OF WAR TO CHEMISTRY IN AMERICA.*}

\author{
By James R. Withrow.
}

War is an evil beyond the power of language to express. To kill one's neighbor or one's enemy is so repellant a thought that one cries out in horror at the idea and instinctively wants to refuse to have any part in action or government which involves such baseness irrespective of the provocation. It is only with the greatest difficulty that we persuade ourselves to act together in any such capacity except in spontaneous defense. Were it not for the religious emphasis upon our duty to support the civil magistrate in the execution of righteous law, and therefore to resist aggression against such law, we would find little ground to stand upon in our present crisis, except it be the desire to bring annihilation upon the philosophy which gave rise to this world war.

It has become more and more apparent that we have been dealing with a power in the case of Germany that is as unscrupulous as her acts are unmanly and cruel, and that the complaints of her opponents against her since 1870 have probably not been overdrawn. The pall of horror and indignation which fell upon us during the invasion of Belgium and France was

*The annual address before the Ohio Academy of Science, Columbus Meeting, evening of April 6, 1917. 
relieved when the Marne gave hope that there was still power enough in the world to frustrate the dream of the bully. This pall has been slowly growing upon us again, however, in spite of the persistent efforts of the German propaganda amongst us to conceal and belie the reports of the damnable conduct of their armies and government at home and in the hapless countries for a time at their mercy. Because of these things we see men everywhere bowed down and depressed as it becomes clearly demonstrated that science, mental endowments and education are no specifics against a wicked heart. These things we really knew before but refused to believe. They are demonstrated to us now by appalling examples so that the whole thinking community has become so mentally and spiritually depressed that one has great difficulty in going about one's normal work, health is damaged and continued research is a matter of great difficulty. A nation of unusual opportunities, great mental endowment and development in science seems to have become the willing or at least easily manipulated pawn in the hands of the unscrupulous statesman. We have not forgotten that it was a chemist Ostwald, in the early days of the war when he was acting as spokesman for Germany to men of science throughout the world, who was quoted, when Germany was in the flush of her initial victories over Belgium, as saying, the world had outgrown the idea of freedom for little or weak peoples.

War, therefore, is a universal mental depressant and as such alone, must damage progress in science. It saps national energy and material resources. It destroys the life of the younger generation of scientists and in large part, the student material from which the scientists of the future are recruited. It interferes with systematic research in many lines by mentally depressing the workers, placing insuperable difficulties in their path and at times by destroying priceless work, records and literature. Certainly war is not desirable to science, even if we could restrain our detestation of it and all its works.

Bitterly as we may condemn war, we would be wrong, however, to claim that science stagnated or declined in war time. Since war requires brains, science is of course utilized, and since the demand is inexorable, science must produce, and when science and engineering are producing, they grow. We have come to learn that modern war is a scientific business under- 
taking. It involves the use of all vital human endeavors, and therefore to varying extent, of all applied science. On the one hand, it involves the utilization of medical science to maintain physical efficiency and speedily repair damage to the fighting machine. On the other hand, it involves the utilization of agricultural, physical and chemical science in feeding and clothing the whole military and naval establishment, and manufacturing the equipment, armament, and "concentrated energy" or explosives consumed by the fighting force. It is stated that it requires three men in the shops to maintain one man in the army and seven men for one in the navy. It is evident, therefore that it is the applied portions of science that are most used and hence that grow most under war's influence. It is common experience, however, that the stretching into new domains and the striving for new goals by applied science enriches the feeding ground of unapplied science and uncovers fertile fields for the patient and quiet research which follows and which often becomes the very backbone of science itself. These results are scarcely visible and will not mature in any event, for years after the war, so that we can see at present little good effect upon unapplied science and we feel quite certain that the reverse influences have the upper hand.

Although it would not be wise at present even if we had the time to go into detail in discussing this subject, nor would it profit you particularly, yet it may be useful to emphasize certain points of view which come sharply to our attention when we attempt to survey the field.

\section{WAR'S DAMAGE TO UNAPPLIED CHEMISTRY.}

We could scarcely expect to estimate the retarding effect of the war on chemistry, because we cannot pry into it deeply and broadly enough to prove our impressions, for research is partly in the minds of scientific workers. However, certain signs of influences actually exist which tend to weaken and retard progress. The American Chemical Society of some 9,000 members, the largest chemical society in the world, publishes twice a month the journal "Chemical Abstracts. Its editorial offices are in the Chemistry Building, a few steps from the one in which we are now assembled. "Chemical Abstracts" has for some years covered the field of chemistry by abstracts more thoroughly than any foreign journal of the kind. It reviews 
some 600 journals from all parts of the world and there is spent upon it by the American Chemical Society an annual budget of over $\$ 40,000$. It is easily seen that this must be the most powerful and most important agency for research in chemistry, and perhaps also in any science, that exists in the world. Some quantitative idea of the evil effect of the war upon chemistry in general may be gotten from its effects upon this colossal agency for assisting applied as well as unapplied research in chemistry.

Inquiry to the editor of "Chemical Abstracts" developed that the effect of the war on current chemical literature as reflected in "Chemical Abstracts" may be shown approximately by the following statement:

"Total No. of abstracts published (patents included):

In $1913-25,971$

In $1914-24,388$

In $1915-18,449$

In $1916-15,784$ "

These figures are fairly representative of actual publication of original papers of more or less direct interest to chemists as Chemical Abstracts has continued closely to approach completeness in spite of war conditions. The quality of the papers being published is somewhat below the normal standard. Not a great many foreign chemical journals have entirely ceased publication since the war started, but all show more or less marked decrease in the number of pages turned out. Most of the French and German journals are published much less frequently than in normal times, two or more numbers being grouped under one cover. Apparently no important English, Italian or Russian chemical journal has ceased publication since the war started. The following list includes the journals concerning which we have uncertain information, but which indicates that they have probably ceased publication due to the war:

ENGLISH (one journal):

Chemical World.

German (eight journals):

Bohmische Bierb.

Technikum.

Deut. med. Wochschr.

Leipziger Farber-Ztg.

Silikat-Z.

Zentr. Exp. Med.

$Z$. exp. Med.

Z. Hyg. 
French (thirty-one journals):

Ann. Mines.

Arch. biol.

J. des. fabr. sucre.

Arch. intern. pharmacodyn.

Arch. intern physiol.

Arch. med. exp.

Betterave.

Brass. malt.

Bull. sci. pharmacol.

Bull. soc. franc. min.

Bull. soc. geol. France.

Bull. soc. ind. Amiens.

Bull. soc. ind. min.

Bull. soc. ind. Mulhouse.

LeCuir.

L'Engrais.

J. d'agr. trop.

J. physique.

J. sci. math. phys. nat.

Radium.

Mon. ceram. verr.

Mon. teint.

Nord Brass.

Papier.

Petit brasseur.

Rev. chim. appl.

Rev. chim. ind.

Rev. electrochim.

Rev. viticulture.

Rev. gen. mat. color.

Sucrerie Ind. colon.

Austrian (one journal):

Oester. Z. Berg. Huttenw.

BELGIAN (seven journals):

Bull. acad. roy. med belg. Rev. intern. pharm.

Bull. sci. acad. roy. belg.

Bull. soc. chim. belg.

J. pharm. soc. d'anvers.

Sucrerie Belg.

Chimiste.

The cost of publication of Chemical Abstracts has been increased by about $10 \%$ as a result of the war. This is chiefly due to the increased cost of paper. The same percentage increase will enter into the cost of the Decennial Index to Chemical Abstracts, which is about to be issued by the American Chemical Society at a cost of over $\$ 30,000$.

Need we go further for evidence of the ill effects of war upon science? Certainly it takes little insight to see that this stoppage or at least side-tracking of the wheels of chemical research will be felt in this science for years to come.

\section{WAR'S RELATION TO APPLIED CHEMISTRY.}

In considering the applied side of chemistry let us remember that war is essentially engineering. Its object is to overcome natural and artificial obstacles. It must therefore get results which are deliberately selected at the will of those directing the war. It insists, therefore, that everyone and everything must produce. Its main agents are engineering and applied chemistry, the engineering, because it struggles with the problems of space 
and time and material for tools and weapons, and applied chemistry, because it is a necessary handmaiden to efficient engineering, and in addition furnishes the source and vehicle for convenient and effective handling of energy in the most concentrated forms. The chemical energy of the modern high explosive is the strong right arm of the fighting force and without it, armies are but chaff. With British control of the seas, German armies with all their numbers, thorough equipment and splendid miiltary power, would have been impotent in a few weeks or months without the chemical ability to get nitric acid from atmospheric nitrogen instead of Chilean nitrate, for without nitric acid high explosives and even smokeless powder are impossible.

The time at our disposal is too brief to touch on all the divisions of applied chemistry. Much progress, for instance, has been made in the domain of the special branch called engineering chemistry, which involves among other things, the chemical investigation of materials for alloys, shrapnel, aeroplanes, submarines and other war supplies. It would be unwise now that we have become involved in the war, to deal publicly with some of the improvements in this field, for they are vital as well as interesting. Some of us have followed the policy during the last three years of not even discussing with our colleagues or students such innovations of military importance in this and the allied countries as have come to our attention, which might by any means percolate into Germany. The branch of applied chemistry known as metallurgy, in which this country is perhaps the most highly developed in the world, also renders distinct service in war time because it is vital to engineering and in the production of arms and ammunition.

We, however, will emphasize more particularly the twin fields of industrial chemistry and chemical engineering, because in the nature of things this field is less popularly known even among chemists. Industrial Chemistry is that branch of chemistry which uses all the rest of chemistry and much engineering, for the furtherance of production of chemical substances, or, the use of chemical means or methods for manufacturing any material of commerce. Chemical engineer-ing is that branch of engineering and industrial chemistry which applies engineering principles and methods to chemical man- 
ufacturing or production. Because their aim is production, these two fields have been largely dominated by war conditions for the past three years. On them the war has had two mutually antagonistic effects, the one retarding or injuring and the other developing and benefitting.

\section{WAR'S DAMAGE TO CHEMICAL INDUSTRY.}

The main factors vital to success in any chemical industry are:

1. Thorough knowledge of an assured market.

2. Possession of at least one well studied and workable chemical process and chemical ability to handle it economically under varying raw material and finished product markets.

3. Possession of engineering ability to carry out and maintain in operation the chemistry involved in the process.

4. Sufficient margin of profit to attract capital and business confidence in chemical and engineering ability in meeting the problems of the field.

Anything or anyone who weakens or strikes at any of these four factors is an enemy of chemical industry and does damage to it.

When war was declared in Europe stagnation set in at once in the chemical industries and indications of disaster were the rule in many of them. Petroleum refining, turpentine, rosin and wood products among others were hard hit because we are strong exporters and such industries as mixed fertilizer manufacture also, because we import heavily of potash. This stagnation could not last long, since the chemical industries underlie the whole fabric of modern industrial development and civilization, and production is necessary to life. Eventually, therefore, the chemical industries were forced to resume operations but great uncertainty as to markets rendered operations difficult and held back many changes in processes and equipment, rendered necessary by changes in source or kind of raw materials. The nature of these industries is often such that the failure of supply of one chemical raw material even if used in but limited amounts may prove fatal by rendering the product unsatisfactory to the market if indeed it is not entirely valueless. A good illustration of the vital importance of accurate knowledge of the market in these chemical industries is furnished by the dye situation, where we had recently the 
anomalous condition of bitter complaint of shortage by consumers simultaneously with utter inability of some producers to market their product, and still other producers with large contracts for product and inability to produce due to poor deliveries or failure of equipment. These difficulties do much harm, since they tend to discourage capital and it must not be forgotten that industrial chemical development is impossible without capital. German chemical manufacturers understood this clearly when they organized American branches of their color works, eliminating American employees to conceal the market and its peculiarities, and placing all their business in the hands of "American citizens" of German name. Then when the U. S. Bureau of Foreign and Domestic Commerce attempted last September to publish the amounts of each dye consumed in this country, they vigorously protested that their rights as American citizens were being infringed by encouraging competition. The uncovering of this octopus to public gaze should be set down to the war's credit. It has long been a familiar animal to many industrial chemists.

Another evil effect of war, a common one now greatly intensified, is the discouragement of capital by failure of hasty and ill-advised manufacturing projects. Successful speculators and others have been influenced by the potential earning capacity of industrial chemistry and have jumped into projects with little study and no experience. Often such capital has not known enough to employ chemical engineers, but has put growing works into the hands of electrical and mechanical engineers whose general engineering sense has not always saved them from physical disasters that chemical experience would have avoided. Such engineers and capital and sad to say, many chemists, who either, lacking entirely in manufacturing experience or having had manufacturing experience, though they acquired no sense of responsibility to protect capital against hazard from decisions without basis in experience, have been the easy victims of the machinery and equipment company who needs but to see a plant, or a picture in a book, and they will design you one while you wait. There not being the proper engineering check, such plants fail at times with regretable loss of life as well as capital and confidence in things chemical, or if they succeed (because the process is simple and well known) the plant can be counted upon to cost from 50 to 100 or more per cent. higher than it should. 
The equipment companies and their engineers are not necessarily dishonest. They sell equipment, and who but they are responsible if they do not sell you enough equipment when you consult them for advice in designing your plant? They, therefore, sell you enough. Experienced engineers will often cut the estimates of such equipment manufacturers in half.

Another illustration of how this situation works out in practice might be given in the case of benzol refining. This is an important matter in modern high explosive manufacture. Some little time ago the best text ever written in English on Industrial Chemistry contained a chapter by a chemical engineer who had ample opportunity of observing the best American practice (which happens to be second to none in the world). His chapter on this subject, therefore, is a classic, but in illustrating the text he did not reproduce details of stills, for instance, with engineering exactness but allowed the artist who made the drawings considerable leeway to his imagination. In fact, he left out entirely a vital feature in the construction of such stills. Were it not for the loss of efficiency and the expense involved, you would be greatly amused if you could go with me to a number of the refineries built in this country in the last two years under war pressure by machinery companies, for good engineers who were not themselves experienced in this industry, but who needed the industry as one of the links in their larger operations. In every case the stills were built exactly patterned after the picture in this text and in no case were they efficient or as nearly efficient as was possible, if a little thought regarding the use to which they would be put had been given them. They were built to sell, not to operate.

The same capital, newly invested in chemistry, is also the easy victim of another evil which is necessarily costly to industrial chemistry and is a heavy blow to the whole science. This evil is the ignorant or unscrupulous chemist. The great difference between industrial chemical research and other chemical research is that the former must produce results on the problem in hand while the latter may ramble if necessary into less difficult fields. When inexperienced capital is seeking chemical assistance the first individual it meets who claims to be a chemist is assumed to be competent to handle any problem without inquiry into his past experience. This same capital 
would scarcely employ a bridge engineer to design a dynamo, yet plant after plant for chemical manufacture has been constructed in the last two years in this country with no more intelligence than this. As a result literally millions have been squandered and lost in these unsuccessful plants. But unfortunately, enough such plants are successful, that their authors escape the penalty of their dishonesty, and therefore, the evil persists and continues. Plants have been constructed for the manufacture of high explosives by engineers who knew nothing of the business, resulting in great loss of property and even life from their final destruction, or in abandonment where they proved unprofitable. I have heard of plants erected for the concentration of sulfuric acid in which a battery of stills for this purpose costing in the neighborhood of a quarter of a million dollars was placed in operation without even a single experiment preliminary to erection, on the type of material to be used, and not even a trial run on one of the stills before all were placed in operation. The first day they operated was the last day, for they all went into solution in the acid.

Men who were or claimed to be chemists have read how simply some reactions described in the general chemistries work, and designed a plant upon their nerve or-as they thought-common sense, and found to their consternation that under the conditions they made for themselves the reaction did not proceed at all, or they were so inexperienced in large scale operations that they could not recognize what they had when the work was under way. Others have so far lost their heads by publicity or financial possibilities, even though good chemists, that they have assumed that what could be done with raw material from one source could be equally well done with it when from another source, provided they merely proved its actual presence in the new product. Ignoring the whole history of chemical as well as industrial chemical development that the chemical environment profoundly affects chemical reaction, no adequate confirmatory studies were made before capital to the extent of hundreds of thousands of dollars has been induced to invest in such guesses, with disastrous results to capital and grave loss of confidence in chemical research. These things are in large part due to or at least the losses could only be so heavy under war pressure. Processes which gave every promise of success have been hurried into failure or near 
failure by undue publicity giving premature capitalistic confidence in them and it is with profound regret that we see the passing for the time at least of such things as toluol from petroleum, which more attention to study may still make useful in war emergency at least.

These are outlines of some of the evil influences due to or accentuated by war. They are in part of such a technical or professional nature that they should not be imposed upon your attention unless it were to protect you against misunderstanding the just criticism of the results of these evils and to emphasize that we do not consider war an unmitigated blessing if we should appear enthusiastic about the progress that has been made in war time. Then too, we should always ponder more over our lapses. The successes can take care of themselves.

\section{PROGRESS IN APPLIED CHEMISTRY IN WAR TIME.}

There is indeed another side than the evil we have been discussing. There has been much real progress. The evils mentioned are largely growing pains. Engineering and its services to mankind have been long appreciated to some extent at least. Chemistry is less easily understood. The everywhere present applications of chemistry pass unnoticed for the most part in everyday life. Probably the greatest contribution to science, therefore, of the present war, is the awakening of the average mind to the power and value to mankind of that group of phenomena which we study as chemistry. This is probably because we most easily grasp and appreciate applications rather than generalizations, and the use of chemistry in war has been a revelation to the general public.

In other ways also this war has affected a development in chemistry and its applications which has outstripped any influence since the modern foundations of the science were laid over a century ago. It will be many years before the influence will mature and become apparent or measurable. Nevertheless, we do not crave progress or development at such a price as war.

We must recognize, however, that severe disturbances are very effective in dislocating fetishes, for instance. So, one of the phases of this struggle which is noteworthy is the public awakening to consciousness of the power of chemistry and the 
universal distribution of the ability to use it promptly and effectively, as against the old idea, that this power and this ability is possessed by a chosen few. An illustration or two will perhaps show that this latter idea is still too prevalent.

I have met manufacturers since the war whose operations were brought to a full stop by lack of some raw material or other who complacently accepted their fate on the ground that they could not get a German chemist. They had no bias in favor of Germany at all. They just thought it was a matter of common information that chemists were domestic animals imported from the Black Forest. Would you believe that some of these manufacturers were engineers graduated from some of our large colleges of engineering and not men without education?

In such a time as this we see that our keeping quiet about the progress and development of American chemistry in years gone by, was criminal, for much harm results from lack of information as well as from misinformation. There are always patriotic Germans and others who praise their country's achievements to us and as I pointed out last year in your OнIо JoURNAL OF SCIENCE, we are glad to see this and our University teachers of chemistry have been lavish in their praise, particularly of German chemistry. They, however, are not rendering very good service to the community when, as they should, they give such praise if they fail to make a real effort to find out also what is going on in their own country. We university professors feel abused if it is inferred that we are not well informed, yet we innocently assume as the only modern development in chemistry the latest tale of achievement from a German dye advertisement and these lads know how to use the educated public and university chemistry professors as well, in furthering their advertising propaganda. Much good work has been done by the "Journal of Industrial and Engineering Chemistry" in publishing a series of articles by authorities, on what the American Chemist has done for the individual industries. Time only will eradicate the evil. Only a short time ago I was at a banquet of a society of engineers in an eastern city. The professor of chemistry from a nearby university was an invited speaker. He was a revered and respected man among American chemists and a man of affairs, too, but he lived in the dark ages of chemical achievement. He spent half of his time telling how wonderful chemistry was and how great the achievements of 
foreign chemistry in particular, and not one word of American chemistry. Yet in his own city in the last three years has sprung up a chemical industry that is marvelous, and which he did not know existed. In his own line, organic chemistry, was a plant for making certain organic materials used in war by a series of steps that has no counterpart in chemical literature for the magnitude and conception of its chemical engineering operations. It is not only the largest scale upon which all of its many operations have ever been conducted but its chemistry is a series of highly interesting adaptations and developments. When peace comes again, if that plant still prospers it will be a useful aid in the solution of one of our most important engineering problems of this generation. Americans are not wizards that they do in two years what it took German chemists decades to work into. Such things are only done where the ability exists and the power born of experience in solving similar chemical problems, is possessed. It is not right to our students, you who teach, to praise the competitors of our compatriots and never stir yourselves to be informed on what our own countrymen are doing, even if, the foreign achievements are served up to us, ready to teach as paid advertisement of German dyemakers. The German general staff has learned, if others have not, that German chemical achievement which is great indeed, is no sign that equal ability does not exist elsewhere. The Allies and America improvised a munitions industry in two years to match their machine of forty years preparation. Such an achievement is only the natural result of our present industrial chemical development in America and the Allied countries. There is nothing in the rate of American industrial chemical development of which any American need be ashamed.

The progress in industrial chemistry and chemical engineering in the last three years itself, in this country, has been wonderful. Let me protest, however, that this is no ground for the philosophy which I understand obtains in some quarters, that war is a desirable, natural, logical or sort of evolutionary benefit. All this progress is in spite of war. War could force us to do nothing we did not possess capacity for before. Because war changes the normal relations between supply and demand, cost and selling price, gives us opportunities to do only what we could do anyway, if the same demand arose from any other cause. 
Industrial chemical tendencies during the war have been governed by unusual demands for chemicals from abroad in addition to war drains, healthy home requirements, new demands from industries formerly supplied from abroad or forced to use new raw material by scarcity or high prices, together with speculation, raising prices to unusual levels. This resulted in expansion of existing plants, rapid installation of new ones, hasty perfecting of new processes already slowly maturing and the seizing of opportunities to profit by high prices through erection of small plants for the production of special chemical materials and through the development of processes hitherto existing as possibilities, only, in the minds of chemists. This has greatly extended also the supplying of chemical construction materials and machinery and has increased the opportunities for the rapid development of inventions in this line. The progress made here alone has been as great as has been accomplished in many individual decades in the past. The importance of this is apparent when we consider that if the chemical engineer had at his disposal as efficient apparatus and materials of construction in his plant, as exist in the chemical laboratories of the present day, or as the mechanical and electrical engineers have in their work, progress in the arts would be at least a hundred years ahead of its present development.

The tendency to manufacture at the market is another good development which has been greatly accentuated by the war. For some time there has been a growing tendency for manufacturers who are large consumers of chemicals to produce these chemicals themselves. Assisted by gradual price elevation, this tendency has been greatly encouraged by the invention in the last two decades of processes and machines of merit which could find no sale as such, in well established chemical manufacturing plants, because they frequently offered insufficient advantages to warrant discarding those already operating, or were merely alternative in their character. A good example of how this tendency to manufacture at the market, works out normally where the impelling force is merely gradually advancing prices, competition preventing excessive elevation, is to be seen among others, in the case of bleach for paper manufacturing. Consumers of alkali and bleach, such as progressive paper manufacturers, operating on a large scale, and others have 
experimented for years with inventions for the electrolytic production of these materials from common salt. Our present high development in this branch of chemical industry is in no small degree due to these individual efforts, many of which during the past twenty years have been eminently successful. High prices and poor deliveries in the last two years have forced matters to a head in this direction. Where formerly we had a few large chemical plants manufacturing caustic soda and chlorine for bleach by electro-chemical means, we now have distributed throughout the country a great number of concerns who have added to their equipment a plant for the production of these products. The operation of these units under widely diverse conditions will greatly enrich our chemical engineering experience. A number of cell types are obtainable which operate economically. Some of these are well advertised in the current literature, but some though equally successful, such as the Allen-Moore, Gibbs, and Nelson Cells, are not so well known. The cell portion of such a plant is only a fraction, however, of the equipment required and it is important that the rest of the plant should be properly designed. The simpler and more durable, therefore, the design of apparatus, the more satisfactory the entire equipment will be. There has been placed in operation in some eight plants recently a total of nearly 2,000 cells of one type alone, with a daily capacity of 200,000 pounds of chlorine gas. Some plants constructed this year cost as much as a half million dollars. These will be valuable for defense, for we use much chlorine in making guncotton or nitro cellulose for mines and smokeless powder.

This use of alternative inventions is valuable in encouraging new invention and much industrial chemical investigation, and alleviates to some extent the ill effects of unwarranted increase in selling prices.

Progress in Chemical Engineering may be illustrated perhaps best by the progress in acid making equipment. High pressure manufacturing of chemicals and difficulty of obtaining supplies has brought rapid improvements and development of chemical engineering materials by compelling large scale experimentation of new products and substitutes. To resist corrosion by acid and other chemicals, pottery or so-called chemical stoneware, glass and natural stone apparatus have been used heretofore. 
This necessitated small sized apparatus, and meant in the case of stoneware a manufacturing time of about two months for the clay working, drying and cooling after firing. Attempts have been made for many years to replace this material by metal. Platinum, silver and gold are used in special cases, but while these metals can be made into any size apparatus, cost is prohibitive for most uses. 'Two classes of alloys have now been developed: rare metal alloys, such as tungsten, chromium, or nickel irons, and more recently the cheaper and more resistant silicon-iron alloys. Extensive trials in the last two years have shown the usefulness of these alloys though they do not possess quite the resistance of stoneware to corrosion. They are known under varying trade names, such as durion, made here in Ohio, tantiron, and ironac. They are very resistant to all strengths of sulfuric and nitric acids and are used with great satisfaction in their manufacture and permit plants to run for months without shut down. The success of the modern tower system displacing platinum for concentrating sulfuric acid has been largely due to the use of pipes and fittings of this alloy.

Early in 1915 the demand for nitric acid for war purposes increased to enormous proportions resulting in extensions to old nitric acid plants and the erection of new ones larger than the world had ever seen. Deliveries on stoneware jumped to six months and even longer and had the production of nitric acid been dependent upon stoneware alone, as a few years ago, it would have been greatly curtailed and the story of the great war would have been different. As these alloys can be secured on short notice, the same as cast iron, chemical manufacturers do not hesitate if a still should run wild and froth sodium sulfate into the condenser to direct workmen to break the connections at once with a hammer and allow the expelled material to flow on the floor, thus preventing the wrecking of the condensing apparatus. New castings can replace the broken one at once. Such extravagant handling of the material would not be possible under the usual slow deliveries with stoneware. This freedom from risk of damage to condensers and the making of condensers themselves of this material, enables stills to carry a heavier charge and be operated at greater speed. Where the old equipment charged $2000 \mathrm{lbs}$. once or twice in twenty-four hours, these war-time stills operate on $6000 \mathrm{lbs}$. of nitre, plus $4000 \mathrm{lbs}$. of sulphuric acid, charging 
three times per twenty-four hours. The alloy is somewhat brittle, but very much less so than chemical stoneware. It is easy to see these silicon-iron alloys are a boon to the acid industries and thousands of tons of castings are in use and new chemical processes are possible and now in operation, too, which could not exist before, because of lack of suitable material of which to construct apparatus. Some of these new processes are having a decided value in the Allies' campaigns. No single development in many decades has had as much influence as this one has, and will have, for it is only in its infancy.

I need not weary you with other illustrations of progress though much has been accomplished in many lines and radically new chemical processes developed. The most wonderful and greatest chemical works I have ever seen have been erected in this country since the war began and the best of them were coal-tar dye and synthetic organic chemical works. Reasonable progress has been made in American laboratory glass and porcelain. After the war we are going to be independent of importation in gross coal-tar products and practically if not entirely, in ammonia for fertilizers. We are also weeding out the unnecessary use of potash where it replaces soda due to our own careless teaching of chemistry in speaking of and using potassium compounds where sodium serves as well. German potash exporters and others, such as for Saxony manganese, after the war will have an expensive campaign to win us back to these former unwarranted uses of their product.

The relation of chemistry to national defense has been rendered clear by the war, a service of no mean magnitude.

Explosives and asphyxiating gas manufacture are dependent upon labyrinthian chemical engineering operations. It is obviously necessary for adequate preparedness that this country should be self-contained and not dependent upon importation for such supplies as nitric acid, toluol and sulfuric acid for defense. We have the sulfur and pyrites for sulfuric acid. The toluol and other coal-tar products we have ample for our usual needs, but in time of war toluol becomes the basis of "T. N. T." or trinitrotoluol, one of the most effective high power military explosives. The erection of new coke oven plants has but partially met the demand for toluol in the last two years. In defending ourselves this would be too slow, for such installations are difficult to get under successful opera- 
tion in less than a year. A large and well established dye industry, therefore, is vital for defense, for it would produce a bigger demand for coal tar products and toluol production in peace times and its operations are quickly convertible into ones for producing high explosives. It is to be hoped therefore that the German alliance with our textile manufacturers may be broken up during this war so that Congress will be less helpless in fostering this dye industry as a matter of defense than it has been in the past. The expense of storing within the country nitrate of soda imported from Chile, adequate for the nitric acid of munitions production in case of war, would tie up millions. The Government will establish a plant to make nitric acid from the atmosphere. The Norwegian process (electric arc) is stated to require five times as much power, a vital factor, as is required in the making of nitric acid from cyanamide. Germany has installed for making cyanamide, during the war additional equipment costing $\$ 100,000,000$, utilizing over 600,000 horse power and producing about 200,000 tons per year of nitric acid, requiring the most feverish activity for a year and a half on the part of her chemical engineers. We have: some. American suggestions which if successful will take less power than the German method. Any method for nitric acid producing ammonia also, is desirable as an aid to agriculture. Prices asked for power are much higher than abroad and as the cost of engineering is only about $10 \%$ of the total charges in electric power installation, it becomes evident that efficient national defense and economic agriculture depend on more economic banking methods. So in every instance we are confronted with the problems of peace when working out national defense. It should be remembered that our usual source of nitrogen derivatives, the ammonia of byproduct coke, brings with it the indispensable toluol, and no electrical method does this. Before the Government nitrogen plant is built, therefore, it should be a matter of serious inquiry whether the Government's $\$ 20,000,000$ might not bring the same result and give a liberal supply of toluol besides, if invested in by-product coke expansion, for much of our coke is still made without saving by-products.

It is an open secret that the acceptance of war orders in this country strained to the breaking point our best organized chemical industries. The mere request by the allied countries 
two years ago for our soda, benzol, toluol and our explosives for only a small portion of their demands, produced a state of affairs in our industries that was an appalling warning against the time when we would need such things ourselves, for defense, and in immensely greater volume.

It is natural in view of the nature of these defense problems that the engineers and chemists of the country have been serious in the preparedness movement. Thirty thousand engineers and chemists of the United States volunteered without pay to the National Consulting Board for both the Navy and Army to work on the organization of the industries of the country for national defense. The result was much more efficient than any similar organization in the world, for no. government could afford to pay for the expert services involved. This Consulting Board and its successor, the National Council for Defense, have assisted the country to become self-contained for defense, arranged for speedy conversion of industrial plants. into munitions plants and arranged during peace to prevent. useless waste of experienced engineers. Experienced chemical engineers for instance, like naval officers, cannot be trained in a. day or a year, though the analytical chemical control can be taught in a few days to any chemist. The mistakes made by Britain in passing through the blockade materials helpful in explosive manufacture demands that our military authority and foreign office have at its call as wide a variety of chemical experience and advice as possible, and every chemist as well as. engineer in this country is now being card indexed.

If we as scientists ask ourselves individually what we can do to assist in the general defense of our firesides and our ideals, the answer is do our daily work in whatever field it may be, as though it were the most important single thing in the world and particularly do our utmost to assist production and those directly engaged in it, whether manufacturing or agricultural. Then when the government calls upon us for special service we will be ready to attack the problems which only the military arm can formulate for us.

We have touched on sufficient high points to indicate the character of the influence of the war upon chemistry in America. Still other points should be discussed, were there time. Hardly any branch of the science but contributes an important service: to the national defense as well as our normal benefit. 
After all is not chemistry and science itself a petty matter in the presence of this world calamity and the personal suffering ever upon our minds? Have we not often wondered what we had done to be spared to this minute from such things? It may be proper to say we do not quarrel with the German people as such, but with the ideals and acts of their leaders and government. Do not let that point of view toward our neighbor, however, be used by us to excuse our individual responsibility for this government and its every act. We are responsible, and we alone. We have seen conclusive proof in the last three years that science and education are merely aids and not specifics against international immorality and that the devotees of science are as easily misled as others when the leaders too are scientific. Though this war has long become evident as a war for privilege and the exploitation of the weak by the strong, and the doctrine that the state can do no wrong rather than that the state must do no wrong, let us not deceive ourselves that our abolition of aristocratic government is a specific for this malady, for it is not. This is our constant battle still, even under our form of government.

It has become so evident in this war that the intelligent and scientific criminal is a terrible menace, and dislodging him at times such a weary and fatal task, that we must find some way of preventing our leaders and groups or classes, whether governmental or industrial, from becoming this kind of danger.

Have we not reached the time when we are willing to turn to the One who ordained civil government for our good, acknowledge that $\mathrm{He}$ ordained it and not we ourselves, and make our leaders or rulers "Whom God and this people shall choose""men fearing God and hating covetousness?"

The Ohio State University, Columbus. 